\title{
Ammonium enhances resistance to salinity stress in citrus plants
}

Emma Fernández-Crespo, Gemma Camañes, Pilar García-Agustín*

Grupo de Bioquímica y Biotecnología. Área de Fisiología Vegetal. Departamento de Ciencias Agrarias y del Medio Natural. ESTCE. Universitat Jaume I, 12071, Castellón, Spain

Address of authors: ecrespo@guest.uji.es; camanes@uji.es; garciap@camn.uji.es 


\begin{abstract}
In this work, we demonstrate that $\mathrm{NH}_{4}{ }^{+}$nutrition in citrange Carrizo plants acts as an inducer of resistance against salinity conditions. We investigated its mode of action and provide evidence that $\mathrm{NH}_{4}{ }^{+}$confers resistance by priming abscisic acid and polyamines, just as enhancing $\mathrm{H}_{2} \mathrm{O}_{2}$ and proline basal content. Moreover it observed a diminished $\mathrm{Cl}^{-}$uptake as well as an enhanced PHGPx expression after salt stress. Control and $\mathrm{N}-\mathrm{NH}_{4}{ }^{+}$plants have shown optimal growth, however it was observed that $\mathrm{N}_{-} \mathrm{NH}_{4}{ }^{+}$plants have displayed greater dry weight and total lateral roots than control plants, but that differences are not seen for primary roots length. Our results reveal that $\mathrm{N}_{-} \mathrm{NH}_{4}{ }^{+}$treatment induces a similar phenotypical response to the recent stress-induced morphogenetic response (SIMRs). The hypothesis is that $\mathrm{N}-\mathrm{NH}_{4}{ }^{+}$treatment triggers mild chronic stress in citrange Carrizo plants, which might explain the SIMR observed. Moreover, we observed modulators of stress signaling, such as $\mathrm{H}_{2} \mathrm{O}_{2}$ in $\mathrm{N}-\mathrm{NH}_{4}{ }^{+}$plants, which could acts as an intermediary between stress and the development of the SIMR phenotype. This observation suggests that $\mathrm{NH}_{4}{ }^{+}$treatments induce a mild stress condition that primes the citrange Carrizo defense response by stress imprinting and confers protection against a subsequent salt stress.
\end{abstract}

\title{
KEY WORDS
}

Ammonium nutrition; citrus; salinity and SIMR.

\section{ABBREVIATIONS}

$A O S$, allene oxide synthase; DAB, diaminobenzidine; DW, dry weight; FW, fresh weight; GAPDH, glyceraldehyde-3-phosphate dehydrogenase; HFBA, heptafluorobutyric acid; PHGPx, phospholipid hydroperoxide glutathione peroxidase; PR5, osmotin-like; PAs, polyamines; PUT, putrescine; $R D 22$, responsive to dessication 22; ROS, reactive oxygen species; SIMRs, stress induced morphogenetic response; SPD, spermidine; SPM, spermine. 


\section{INTRODUCTION}

Nitrate $\left(\mathrm{NO}_{3}{ }^{-}\right)$and ammonium $\left(\mathrm{NH}_{4}{ }^{+}\right)$are the main inorganic nitrogen $(\mathrm{N})$ resources absorbed by the roots of higher plants. Nitrogen is used to form glutamine, a precursor of many amino acids, like nucleic acids, alkaloids and polysaccharides, as well as secondary metabolites like PAs (Bagh et al.,, 2004). It is generally accepted that many plants display optimal growth and development if nitrogen is available in the form of $\mathrm{NO}_{3}{ }^{-}($Coruzzi and Bush, 2001). Although $\mathrm{NO}_{3}{ }^{-}$uptake consumes more energy than $\mathrm{NH}_{4}{ }^{+}$, only a few plant species display optimal growth when $\mathrm{N}$ is available in only the $\mathrm{NH}_{4}{ }^{+}$form (Marschner, 1995). Camañes et al., (2009) demonstrated that citrus plants prefer to absorb $\mathrm{NH}_{4}{ }^{+}$more than $\mathrm{NO}_{3}{ }^{-}$ when both $\mathrm{N}$ forms are present in the nutrient solution, which is probably due to less energy in the assimilation ion process. $\mathrm{NH}_{4}{ }^{+}$is a paradoxical nutrient ion because, despite being a major $\mathrm{N}$ source and an important intermediate in many metabolic reactions, there are reports that high concentrations of this ion in either soil or the nutrient solution may lead to an “ammonium syndrome". This may include leaf chlorosis, lower plant yield production and root/shoot ratio, lower cation content, acidification of the rizosphere and changes in several metabolites levels, such as amino acids or organic acids (Britto and Kronzucker, 2002). In spite of the information available about the appearance of toxic symptoms due to $\mathrm{NH}_{4}{ }^{+}$ nutrition, different studies have produced contradictory results. This could be explained by each plant's specific and varietal characteristics, and by experimental conditions. Thus, there is a wide range of plant responses to $\mathrm{NH}_{4}{ }^{+}$nutrition; there are some species that are tolerant to high $\mathrm{NH}_{4}{ }^{+}$doses, such as rice (Wang et al., 1993), and some very sensitive species which practically cannot survive under $\mathrm{NH}_{4}{ }^{+}$nutrition, such as tomato or barley (Britto et al., 2001).

Salinity is amongst the most significant environmental factors responsible for substantial losses in agricultural production worldwide and it is one of the serious problems confronting sustainable agriculture in irrigated production systems in arid and semiarid regions 
(Marschner 1995; Ravindran et al., 2007). Nearly 20\% of the world's cultivated area and about half of the world's irrigated lands are affected by this stress (Munns and Tester, 2008). This is a critical problem especially in citrus since they are one of the most globally important horticultural crops considered salt sensitive (Al-Yassin 2005). Salinity causes several injuries in citrus such as tissue burning, loss of yield, leaf abscission and finally plant death (RomeroAranda et al., 1998). Identifying successful strategies that enhance salinity resistance to this plant species is of both agronomic and economic interest. This complex environmental stress presents three different components: an ionic component linked to the accumulation of ions, which become toxic at high salt concentrations (mainly $\mathrm{Na}^{+}$and $\mathrm{Cl}^{-}$) in the cytoplasm, leading to ionic imbalance; an osmotic component due to the compartmentalization of this toxic ion in the vacuole. When this compartmentalization occurs in cells, the cytosol water potential must be lowered to balance the low-external water potential, thus ensuring water intake in the plant cell and avoiding macromolecule damage (Ellouzi et al., 2011). Apart from the toxic and osmotic effects of salinity, a high cellular $\mathrm{NaCl}$ concentration causes enhanced formation of reactive oxygen species ROS (Hernandez and Almansa, 2002). ROS are highly reactive and, in the absence of any scavenging mechanism, they can provoke major alterations in normal metabolism through oxidative damage to lipids, proteins and nucleic acids (Foyer and Noctor, 2005). However, transient ROS formation apart from causing oxidative damage when present at high concentrations can play a signaling protective role in the short term (Dat et al., 2000). The role of some ROS, such as signal molecules in biotic or abiotic stress, is of biological significance because the production of these molecules could benefit the plants brought into a state of acclimation (Foyer et al., 1997, Jubany-Marí et al., 2009). Similarly, plant hormones play an important role in response to unfavorable environmental conditions. They are involved in signaling response to drought and salinity by the activation of acclimation processes such as stomatal closure, regulation of hydraulic conductivity and regulation of 
developmental processes that affect stress tolerance, such as senescence abscission (Sakamoto et al., 2008). Plants are sessile organisms that have developed an extensive array of defensive responses. An important aspect related to response to a range of biotic and abiotic stress is the phenomenon of priming (Van der Ent et al., 2009). Preliminary stress exposure or stress imprinting is indeed necessary to induce priming, which makes the plants more resistant to future biotic or abiotic stress (Conrath et al., 2006; Bruce et al., 2007; Galis et al., 2009). Priming state can be induced by different biological or chemical stimuli. Some quemical inducers are 2,6-dichloro isonicotinic acid (INA), benzo-(1,2,3)-thiadiazole-7-carbotionic acid S-methyl ester (BTH), $\beta$-aminobutyric acid (BABA) (Oostendorp et al., 2001; Conrath et al., 2002) and hexanoic acid, which by root treatment protects tomato plants and Arabidopsis against Botrytis cinerea (Vicedo et al., 2009; Kravchuk et al., 2011). Regarding abitotic stress, BABA has been shown to confer plant protection against salinity and drought (Jakab et al., 2005; Macarisin et al., 2009). Moreover, stress can also boost plant stress tolerance through induction of acclimation responses. Tolerance can be linked to an array of morphological, physiological and biochemical responses which lower the stress exposure limit and damage, or facilitate the repair of damaged systems (Mittler 2002). After exposure to stress, various changes take place, leading to different phenotypes depending on the type of stress, its duration or experimental conditions. However, a common response in all these responses occurs, which is known as "stress-induced morphogenic responses" (SIMRs). Exposure of plants to mild chronic stress could cause induction of these specific SIMRs. These responses are characterized by blockage of cell division in the main meristematic tissues, inhibition of elongation and redirected outgrowth of lateral organs. Furthermore, it is believed that this process brings about a rise in ROS species and alters different hormones (Potters et al., 2007). The induced resistance against abiotic stress in citrus and other woody species has not been explorer, and understanding the molecular mechanisms beneath this 
process will provide the necessary insights to exploit this phenomenon in sustainable agriculture.

In this work, we demonstrate that $\mathrm{NH}_{4}{ }^{+}$nutrition in citrange Carrizo plants enhanced resistance to salinity conditions. We investigated its mode of action, and provide evidence that $\mathrm{NH}_{4}{ }^{+}$primes citrange Carrizo's defenses by enhancing abscisic acid (ABA), PAs and potentiating $\mathrm{H}_{2} \mathrm{O}_{2}$ and proline basal content as well as diminished $\mathrm{Cl}^{-}$uptake.

\section{MATERIAL AND METHODS}

\section{Plant material, growth conditions and nutrition treatments}

citrange Carrizo seeds (Citrus sinensis L. Osbeck $\times$ Poncirus trifoliata L.) (Beniplant, Valencia, Spain) were allowed to germinate in vermiculite in a growth chamber under the following environmental conditions: light/dark cycle of $16 / 8 \mathrm{~h}$, temperature of $20 / 24^{\circ} \mathrm{C}$, light intensity of $200 \mu \mathrm{mol} \mathrm{m} \mathrm{m}^{-2} \mathrm{~s}^{-1}$ and relative humidity of $70 \%$. Seeds were irrigated twice a week with distilled water. After 6 weeks, seedlings were irrigated for two months with Hoagland solution lacking nitrogen (Hoagland and Arnon, 1950) complemented with $1 \mathrm{mM} \mathrm{NH}_{4} \mathrm{NO}_{3}$ (control treatment) and $5 \mathrm{mM}$ of N-NH$\left.{ }_{4}^{+}\left[\left(\mathrm{NH}_{4}\right)_{2} \mathrm{SO}_{4}\right)\right]\left(\mathrm{NH}_{4}{ }^{+}\right.$treatment). Then $1.5 \mathrm{mM}$ $\mathrm{K}_{2} \mathrm{SO}_{4}$ and $3 \mathrm{mM} \mathrm{CaSO}_{4}$ were added to compensate for the absence of $\mathrm{K}^{+}$and $\mathrm{Ca}^{2+}$. The $\mathrm{pH}$ of the nutrient solution was adjusted to 6.0 with $1 \mathrm{mM} \mathrm{KOH}$.

Prior to the experiments, 3-month-old plants with a single shoot were selected for uniformity of size, and transferred to an aerated complemented Hoagland solution for 7 days in hydroponic culture devices.

To salt stress, $90 \mathrm{mM} \mathrm{NaCl}$ were added to the hydroponic solution and renewed twice weekly. Samples were taken for individual analysis at $2 \mathrm{~h}$ and $14 \mathrm{~d}$ after addition of salt to the hydroponic solution. At the end of the experiment, the phenotype was determined by the percentage of leaves with symptoms of necrosis or burns. 


\section{Growth and damage of salt values}

The DW and length primary roots were measured at each sampling. The lengths of the individual primary roots of individual seedling were measured directly. Dry weight refers to the total roots (primary, secondary and tertiary) of the individual seedlings.

To measure the damage provoked by high salinity in the medium soil, we also established three damage levels: healthy leaves, chlorotic leaves (level 1), leaves with necrosis (level 2) and burnt leaves (level 3).

\section{Quantitative RT-qPCR analysis}

Gene expression by quantitative real-time PCR (RT-qPCR) was performed using RNA samples extracted from leaf tissue using the Total Quick RNA cells and tissues kit (Talent; http://www.spin.it/talent). Citrus leaves tissue samples for RNA isolation were collected at 2 $\mathrm{h}$ and $14 \mathrm{~d}$ after $\mathrm{NaCl}$ treatment. Leaf tissue was collected from treated and untreated plants. The RT-qPCR conditions were those described by Flors et al. (2007). A list of the primers used in the RT-qPCR is shown in Table 1, using GAPDH gene expression of citrus how an internal standard.

\section{Chromatographic analysis.}

Hormone extraction and quantification were performed as described in Flors et al. (2008). Briefly, fresh material was frozen in liquid nitrogen. Before extraction, a mixture of internal standards containing $100 \mathrm{ng}\left[{ }^{2} \mathrm{H} 6\right]-\mathrm{ABA}$ and $100 \mathrm{ng}\left[{ }^{2} \mathrm{H} 4\right]-\mathrm{SA}$ was added. Dry tissue $(0.05 \mathrm{~g})$ was immediately homogenized in $2.5 \mathrm{~mL}$ of ultrapure water. After centrifugation $(5000 \mathrm{~g}, 40$ min), the supernatant was recovered and adjusted to $\mathrm{pH} 2.8$ with $6 \%$ acetic acid, and subsequently partitioned twice against an equal volume of diethyl ether. The aqueous phase was discarded, the organic fraction evaporated in a Speed Vaccuum Concentrator (Eppendorf; 
www.eppendorf.com) at room temperature, and the solid residue re-suspended in $1 \mathrm{~mL}$ of a water/methanol (90:10) solution and filtered through a $0.22 \mu \mathrm{m}$ cellulose acetate filter. A 20 $\mu 1$ aliquot of this solution was then directly injected into the HPLC system.

For PAs analysis, fresh material was frozen in liquid nitrogen. Before extraction, according to the method of (Sánchez-López et al., 2009) a mixture of internal standards containing ${ }^{13} \mathrm{C}_{4}$-putrescina and 1,7-diamineheptane, was added. Dry tissue $(0.02 \mathrm{~g})$ was homogenized in $2 \mathrm{~mL}$ of $2 \%$ perchloric acid. After centrifugation $(5000 \mathrm{~g}, 40 \mathrm{~min})$, the supernatant was separated $2 \mathrm{~mL}$ of $2 \%$ perchloric acid were add to the pellet and centrifugation was repeated. Then both supernatants were collected and a mixture of $10 \%$ MeOH and HFBA $25 \mathrm{mM}$ was added until $6 \mathrm{~mL}$. Next $1 \mathrm{~mL}$ of the mixture was taken and filtered through a $0.45 \mu \mathrm{m}$ cellulose acetate filter. A $20 \mu 1$ aliquot of this solution was directly injected into the HPLC system. Analyses of hormone and PAs sample were carried out using a Waters Alliance 2690 HPLC system (Milford, MA, USA) with a nucleosil ODS reversedphase column (100 x 2 mm i.d.; 5 mL; Scharlab, Barcelona, Spain; http:// www.scharlab.es). The chromatographic system was interfaced to a Quatro LC (quadrupole-hexapolequadrupole) mass spectrometer (Micromass; http://www.micromass.co.uk). The MASSLYNX NT software version 4.1 (Micromass) was used to process the quantitative data from calibration standards and plant samples.

\section{Chloride analyses}

Chloride measurements were taken by automatic titration using a chloridemeter (Model 926, Sherwood Scientific Ltd., Cambridge, UK), as described in López-Climent et al. (2008). Briefly, ground plant material was incubated overnight in a mixture of $0.1 \mathrm{~N} \mathrm{HNO}_{3}$ (Panreac, Barcelona, Spain) and 10\% glacial acetic acid (Panreac) under continuous shaking. The 
supernatant was filtered through Whatmann \#1 filter paper and $0.5 \mathrm{~mL}$ used for determinations.

\section{Proline analyses}

Leaf proline content was determined by a spectrophotometric assay, as described in Bates et al. (1973). Briefly, $50 \mathrm{mg}$ of frozen plant material was extracted in $5 \mathrm{~mL}$ of $3 \%$ sulphosalicylic acid (Panreac). After centrifugation at $4000 \times \mathrm{g}$ and $4{ }^{\circ} \mathrm{C}, 1 \mathrm{~mL}$ of supernatant was combined with $1 \mathrm{~mL}$ of glacial acetic acid (Panreac) and $1 \mathrm{~mL}$ of ninhydrin (Panreac) solution. The combined solution was incubated at $80^{\circ} \mathrm{C}$ in a water bath for $1 \mathrm{~h}$ and the resulting mixture was partitioned against $2 \mathrm{~mL}$ of toluene after a cooling period. Absorbance at $520 \mathrm{~nm}$ was read in the organic layer against a blank. Determinations were performed using commercial proline as a standard (Sigma-Aldrich, Madrid, Spain).

\section{DAB staining and $\mathrm{H}_{2} \mathrm{O}_{2}$ quantification.}

$\mathrm{N}-\mathrm{NH}_{4}{ }^{+}$and control plants were exposed to $90 \mathrm{mM} \mathrm{NaCl}$ for $2 \mathrm{~h}$, and the salt-stressed leaves were stained in $1 \mathrm{mg}$ of $\mathrm{DAB}$ per milliliter at $\mathrm{pH}<3$ for $24 \mathrm{~h}$ in the dark and were subsequently destained in 95\% ethanol. Later, samples were rehydrated with distilled water. DAB staining intensities were quantified from digital photographs by the number of darkbrown DAB pixels in relation to the total pixels corresponding to plant material, using GIMP2 program.

\section{Statistical analysis}

Statistical analysis was carried out using the Statgraphics software support. Data are expressed as means and standard error. Mean values were compared by an LSD (least significant difference) test. All experiments were repeated at least three times. 


\section{RESULTS}

\section{Development of the citrange Carrizo plants grown under the $\mathrm{NH}_{4}{ }^{+}$condition}

Three-month-old citrange Carrizo plants were grown for 2 months with Hoagland solution lacking nitrogen, but complemented with $1 \mathrm{mM} \mathrm{NH}_{4} \mathrm{NO}_{3}$ (control plants) and $5 \mathrm{mM}$ $\left(\mathrm{NH}_{4}\right)_{2} \mathrm{SO}_{4}\left(\mathrm{~N}-\mathrm{NH}_{4}{ }^{+}\right.$plants $)$. Although other studies have shown that some species develop toxic symptoms when only $\mathrm{NH}_{4}{ }^{+}$nutrition is applied (Gerendás et al., 1997; Lasa et al., 2001), the citrange Carrizo $\mathrm{N}-\mathrm{NH}_{4}{ }^{+}$plants displayed optimal growth, estimated on the basis of biomass production (Fig. 1A). Moreover, we observed that ${\mathrm{N}-\mathrm{NH}_{4}}^{+}$plants developed a darker green color, and their chlorophyll content was $13.12 \%$ higher than in the control plants (data

not shown). Likewise, the $\mathrm{N}-\mathrm{NH}_{4}{ }^{+}$plants showed vigorous root growth, estimated on the basis of the DW of total roots, which was higher in the $\mathrm{N}_{-} \mathrm{NH}_{4}{ }^{+}$plants if compared with the control plants (Fig. 1C). However, primary root length did not differ between the control and the $\mathrm{NH}_{4}{ }^{+}$treated plants (Fig. 1B). The secondary and tertiary lateral roots of the $\mathrm{N}_{-} \mathrm{NH}_{4}{ }^{+}$plants developed more than control plants. $\mathrm{NH}_{4}{ }^{+}$treatment increased the number of lateral roots per DW of the total roots of the individual seedlings, as well as the number of total roots per primary root length (Figs. 1D and E).

\section{$\mathrm{NH}_{4}{ }^{+}$treatment enhances citrange Carrizo resistance to salt stress.}

The increased levels of $\mathrm{NaCl}$ in the watering solution led to different levels of damage in plants. To achieve salt stress, $90 \mathrm{mM} \mathrm{NaCl}$ were added to the hydroponic solution to the control and the $\mathrm{N}_{-} \mathrm{NH}_{4}{ }^{+}$plants over a 14-day period. In order to check how $\mathrm{NH}_{4}{ }^{+}$nutrition could affect the response of citrange Carrizo plants to salt stress, necrosis and burns on leaves were estimated. The result was expressed as percentage of damaged leaf in relation to the total leaves per plant by establishing the following damage levels: healthy leaves, chlorotic leaves (level 1), leaves with necrosis (level 2) and burnt leaves (level 3) (Fig. 2). In this case, 
significant differences between the control and the $\mathrm{N}_{-} \mathrm{NH}_{4}{ }^{+}$salt-treated plants were noted as the $\mathrm{N}_{-} \mathrm{NH}_{4}{ }^{+}$plants displayed $30 \%$ more healthy leaves than the control plants. Both the control and the $\mathrm{N}_{-} \mathrm{NH}_{4}{ }^{+}$plants had a similar percentage of chlorotic and necrotic leaves but, interestingly, the level of burnt leaves was higher in the control plants.

\section{$\mathrm{NH}_{4}{ }^{+}$treatment reduced citrange Carrizo toxic and osmotic stress}

Salinity tolerance in Citrus is strongly related to leaf chloride accumulation. It is wellknown that $\mathrm{Cl}^{-}$toxicity, rather than $\mathrm{Na}^{+}$toxicity, is the primary factor involved in the molecular responses of citrus plant leaves to salinity (Brumós et al., 2009). We observed that the $\mathrm{Cl}^{-}$concentration in leaves increased in both treatments, in the control and the $\mathrm{N}^{-\mathrm{NH}_{4}}{ }^{+}$ plants upon salt stress (Fig. 3A). The highest leaf $\mathrm{Cl}^{-}$concentration occurred in the control plants at $14 \mathrm{~d}$, at which time the $\mathrm{Cl}^{-}$concentration noted for the leaves of the $\mathrm{N}^{-\mathrm{NH}_{4}}{ }^{+}$plants had reduced by $24 \%$ when compared with the control plants leaves.

It is well-known that soil with high salt concentrations is virtually dry because the available water is trapped by ions. Proline has been considered to play an important role in plant response to salinity (Gaspar et al., 2002) since it acts as a compatible solute that adjusts the osmotic potential in the cytoplasm (Bartels and Sunkar, 2005). In order to assess the effectiveness of $\mathrm{N}^{-\mathrm{NH}_{4}}{ }^{+}$treatment against osmotic stress induced by $\mathrm{NaCl}$, we tested proline content in leaves. The basal proline content differed between the control and the $\mathrm{N}-\mathrm{NH}_{4}{ }^{+}$ plants (Fig. 3B). The $\mathrm{N}-\mathrm{NH}_{4}{ }^{+}$plants had higher proline content at $2 \mathrm{~h}$ and $14 \mathrm{~d}$ in the absence of salt if compared with the control plants. Interestingly the proline content of both treatments significantly increased after salinity, with no statistically significant differences between the control and the $\mathrm{N}_{-} \mathrm{NH}_{4}{ }^{+}$-treated plants. Proline content increased by $19.53 \%$ in the control plants upon salinity treatment, while it increased by only $9.30 \%$ in the $\mathrm{N}_{-} \mathrm{NH}_{4}{ }^{+}$plants. 


\section{$\mathrm{NH}_{4}{ }^{+}$treatments enhance $\mathrm{H}_{2} \mathrm{O}_{2}$ accumulation}

In this work, we used DAB staining to establish how $\mathrm{NH}_{4}{ }^{+}$treatment affects cellular oxidative stress. The $\mathrm{H}_{2} \mathrm{O}_{2}$ staining based on the in vivo reaction of $\mathrm{H}_{2} \mathrm{O}_{2}$ with DAB allows a rapid estimation of $\mathrm{H}_{2} \mathrm{O}_{2}$ accumulation in leaves (Thordal-Christensen et al., 1997). Our results indicate that the $\mathrm{N}-\mathrm{NH}_{4}{ }^{+}$plants show higher initial levels of $\mathrm{H}_{2} \mathrm{O}_{2}$ accumulation than the control plants in the absence of salt stress. Increased $\mathrm{H}_{2} \mathrm{O}_{2}$ accumulation was noted $2 \mathrm{~h}$ after treatment with $90 \mathrm{mM} \mathrm{NaCl}$. Although higher $\mathrm{H}_{2} \mathrm{O}_{2}$ accumulation was seen in the control plants in response to salt stress, the highest levels of $\mathrm{H}_{2} \mathrm{O}_{2}$ accumulation were observed for the $\mathrm{N}-\mathrm{NH}_{4}{ }^{+}$plants treated with $\mathrm{NaCl}$ (Fig. 4)

\section{$\mathrm{NH}_{4}{ }^{+}$treatment induces the main hormone signaling pathways}

In order to establish whether enhanced resistance of $\mathrm{NH}_{4}{ }^{+}$is mediated by the induction of the ABA-, salicylic acid- (SA) and jasmonic acid - (JA ) signaling pathways, the RD22, PR5 and $A O S$ marker genes expressions were analyzed by RT-qPCR (Fig. 5). These genes have been previously reported to be salt stress inducible in different species (Zhu et al., 1995; Nylander et al., 2001; Pendranzani et al., 2003). We observed that $\mathrm{NH}_{4}{ }^{+}$treatments induced $R D 22$ mRNA accumulation in the absence of salt stress and that $R D 22 \mathrm{mRNA}$ accumulation in response to salt stress lightly increased after salinity in both treatments (Fig. 5A). $\mathrm{NH}_{4}{ }^{+}$ treatment induced PR5 mRNA accumulation in the absence of salt stress, however, upon salinity stress both treatments induced the $P R 5$ expression at $14 \mathrm{~d}$, but greater inductions were observed in the control plants than in the $\mathrm{N}^{-N_{4}}{ }_{4}^{+}$plants (Fig. 5B). We also checked JAdependent signaling pathway transduction after $\mathrm{NH}_{4}{ }^{+}$treatment in citrange Carrizo plants. $\mathrm{NaCl}$ treatment induced $A O S$ mRNA accumulation in both treatments, but the $\mathrm{N}^{-\mathrm{NH}_{4}}{ }^{+}$plants exhibited greater accumulation upon salinity when compared with the control plants (Fig. 5C). The expression patterns of the markers genes for the ABA, SA and JA pathways indicate 
that all the pathways were more induced in the $\mathrm{NH}_{4}{ }^{+}$treated plants than in the control ones. In order to further confirm the possible role of the different signaling pathways in $\mathrm{NH}_{4}^{+}$ resistance, we analyzed the hormonal levels in both the control and the $\mathrm{N}_{-} \mathrm{NH}_{4}{ }^{+}$treated plants at $14 \mathrm{~d}$ after salinity stress. The basal ABA levels differed between control and the $\mathrm{N}-\mathrm{NH}_{4}{ }^{+}$ plants in the absence of salt, but were higher in the $\mathrm{N}^{-\mathrm{NH}_{4}}{ }^{+}$plants (Fig. 6A). The control plants revealed increased ABA accumulation $14 \mathrm{~d}$ after salt stress, as expected, but no such increase was observed in the $\mathrm{N}-\mathrm{NH}_{4}{ }^{+}$plants upon salt stress. These initial ABA accumulations suggest that the resistance induced by $\mathrm{NH}_{4}{ }^{+}$treatment could be mediated by this hormone, which plays a role in defense signaling in osmotic and salt stresses (Jakab et al., 2005). The basal SA levels did not differ between the control and the $\mathrm{NH}_{4}{ }^{+}$-treated plants before salinity, but ranged between $25 \mathrm{ng} \mathrm{g}^{-1}$ and $38 \mathrm{ng} \mathrm{g}^{-1} \mathrm{FW}$ (Fig. 6B). Interestingly, the control plants displayed a significant increase in SA accumulation at $14 \mathrm{~h}$ after salinity which was not observed in the $\mathrm{N}^{-\mathrm{NH}_{4}}{ }^{+}$-treated plants upon salinity. No differences in JA levels were observed in either the control or the $\mathrm{NH}_{4}{ }^{+}$-treated plants in the absence or the presence of salt stress (data not shown).

\section{$\mathrm{NH}_{4}{ }^{+}$treatments reduced the oxidative damage caused by salt stress. Polyamines content and PHGPx expression}

PAs play a key role in plant responses to salinity. These compounds have been tested not only as antioxidants, but also as osmoprotectors under salinity conditions (Groppa et al., 2001; Chattopadhayay et al., 2002; Kakkar and Sawhney, 2003). In order to determine whether $\mathrm{NH}_{4}{ }^{+}$treatment affects PAs content, leaf samples were analyzed at $14 \mathrm{~d}$ in the control and the $\mathrm{N}-\mathrm{NH}_{4}{ }^{+}$plants, and also in these plants after salt stress. In the $\mathrm{N}-\mathrm{NH}_{4}{ }^{+}$plants, the concentrations of Put, Spd and Spm were higher than in the control plants in the absence of salt. It is interesting to note that the Put titer increase was especially important. The Put 
concentration in the control plants was $6.16 \mathrm{ng} \mathrm{mg}^{-1} \mathrm{FW}$, while it was $146.98 \mathrm{ng} \mathrm{mg}^{-1} \mathrm{FW}$ in the $\mathrm{N}-\mathrm{NH}_{4}{ }^{+}$plants. However, the Put, Spd and Spm contents remained unaffected in the control and the $\mathrm{N}_{-} \mathrm{NH}_{4}{ }^{+}$plants after salt stress (Table 2). Put accumulations in $\mathrm{N}^{-\mathrm{NH}_{4}}{ }^{+}$plants suggest that the resistance induced by $\mathrm{NH}_{4}{ }^{+}$treatment could be mediated by this polyamine, which reduces salt-inducible oxidative damage (Groppa and Benavides, 2008).

In order to establish whether the enhanced resistance of $\mathrm{N}^{-\mathrm{NH}_{4}}{ }^{+}$treatment to salt stress is mediated by the induction of antioxidant activity pathways, the PHGPx gene expression was analyzed by RT-qPCR. It has been previously reported that PHGPx is a unique intracellular antioxidant enzyme that directly reduces phospholipid hydroperoxides produced in cell membranes under salt conditions, and has been considered the main line of enzymatic defense against oxidative biomembrane damage in mammalian cells (Chun-Juan et al., 2009).

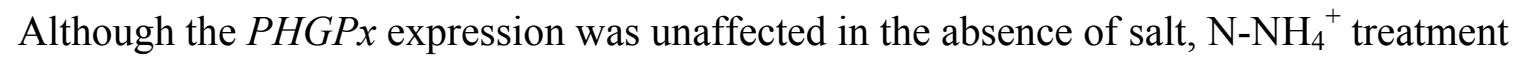
enhanced this expression at $14 \mathrm{~d}$ after salt stress.

\section{DISCUSSION}

In this study, we have analyzed influences of $\mathrm{NH}_{4}{ }^{+}$nutrition on citrange Carrizo plants undergoing $90 \mathrm{mM} \mathrm{NaCl}$. citrange Carrizo plants were grown with $1 \mathrm{mM} \mathrm{NH}_{4} \mathrm{NO}_{3}$ (control plants) and $5 \mathrm{mM}$ de $\mathrm{N}-\mathrm{NH}_{4}{ }^{+}\left(\mathrm{N}-\mathrm{NH}_{4}{ }^{+}\right.$plants), they showed optimal growth in both treatments. However, we observed that the $\mathrm{N}^{-\mathrm{NH}_{4}}{ }^{+}$plants had greater DW and total lateral roots than the control plants; yet these differences were not noted for primary roots length. It is commonly accepted that the root system is critical for nutrient and water uptake from soil, and that it displays considerable plasticity in response to development and environment signals (Li et al., 2010). Primary root growth is often diminished in stressful soil environments, such as those deficient in phosphate (Svistoonoff et al., 2007) or with excess aluminum (Jones and Kochian, 1995). Previous results have shown that stunted root systems 
are a significant symptom of $\mathrm{NH}_{4}{ }^{+}$toxicity and confirmed that $\mathrm{NH}_{4}{ }^{+}$in soil inhibits primary root growth, being cell elongation but not cell division, the principal target in $\mathrm{NH}_{4}{ }^{+}$inhibition (Li et al., 2010). We have demonstrated that $\mathrm{NH}_{4}{ }^{+}$treatment induces lateral root development in citrange Carrizo plants. This is supported by the findings of Yang et al. (2011), who observed that $\mathrm{NH}_{4}^{+}$stimulated root hair branches in Arabidospsis which may be directly due to a response to $\mathrm{NH}_{4}{ }^{+}$toxicity or $\mathrm{NH}_{4}{ }^{+}$-induced stress signals. Moreover, it has been suggested that ROS may be an $\mathrm{NH}_{4}{ }^{+}$-induced stress signal leading to the formation of hair branching. Moreover, it demonstrates that citrange Carrizo plants grown under $\mathrm{N}_{-} \mathrm{NH}_{4}{ }^{+}$ conditions are more resistant to salinity stress. Salinity stress was induced by the addition of $90 \mathrm{mM} \mathrm{NaCl}$ for $14 \mathrm{~d}$ to the control and the $\mathrm{N}_{-} \mathrm{NH}_{4}{ }^{+}$plants. After checking for any damage induced by salinity, we found a differential response to salt stress, and the $\mathrm{N}^{-\mathrm{NH}_{4}}{ }^{+}$plants presented less damage than the control plants. These data suggest that $\mathrm{N}-\mathrm{NH}_{4}{ }^{+}$treatment produces some response mechanism which benefits citrange Carrizo plants to better tolerate exposure to $90 \mathrm{mM} \mathrm{NaCl}$. Salinity is a complex environmental stress that presets three different components: an ionic component linked to the accumulation of ions, mainly $\mathrm{Cl}^{-}$in citrus plants (Brumós et al., 2009); an osmotic component due to compartmentalization of this toxic ion in the vacuole, which triggers accumulation of low molecular-weight osmolytes (Zhu et al., 1998); and increased ROS formation, which is considered the primary event under a variety of stress conditions (Hernandez and Almansa, 2002). $\mathrm{N}-\mathrm{NH}_{4}{ }^{+}$-treated plants are capable of reduced $\mathrm{Cl}^{-}$leaves accumulation after $14 \mathrm{~d}$ of salt exposure. The high shoot $\mathrm{Cl}^{-}$ level in the salt-treated control plants indicates this ion's poor capacity to prevent translocation to shoots. However, ${\mathrm{N}-\mathrm{NH}_{4}}^{+}$treatment helps avoid leaves from accumulating $\mathrm{Cl}^{-}$ , probably by the inhibition of chlorid channel-like (CLC) proteins, as observed in barley (Lopes and Araus, 2008). Moreover, soil with high salt concentrations is practically dry because ions trap any available water. To overcome this problem, citrus responds by 
overproducing compatible osmolites such as proline (Bañuls and Primo-Millo, 1992). For a long time, proline has been considered an inert compatible osmolyte which protects subcellular structures and macromolecules upon osmotic stress (Kishor et al., 2005). Several studies have shown that proline is a potent ROS scavenger associated with the prevention of apoptotic-like PCD (Chen and Dickman, 2005). Proline content in the $\mathrm{N}_{-} \mathrm{NH}_{4}{ }^{+}$plants at $2 \mathrm{~h}$ and $14 \mathrm{~d}$ in the absence of salt is higher than in the control plants. Yet under salt conditions, both treatments showed an increased proline accumulation. The highest basal proline content in the $\mathrm{N}_{-} \mathrm{NH}_{4}^{+}$plants could confer initial protection to salt stress since proline accumulation in stressed plants has been associated with enhanced tolerance to abiotic stress conditions (Szabados and Savouré, 2009). Furthermore, it is well-known that salinity increases cellular ROS accumulation (Hernandez and Almansa, 2002). Although ROS can induce severe cellular damage, these molecules are important in signaling, since control, among others, the expression of stress tolerance (Foyer and Noctor, 2005). Control and N-NH${ }_{4}^{+}$citrange Carrizo plants display considerably increased $\mathrm{H}_{2} \mathrm{O}_{2}$ accumulation $2 \mathrm{~h}$ after salinity stress. It is noteworthy that the initial $\mathrm{H}_{2} \mathrm{O}_{2}$ levels were higher in the $\mathrm{N}^{-N_{4}}{ }_{4}^{+}$plants than in the control ones. This result supports the idea that $\mathrm{H}_{2} \mathrm{O}_{2}$ could act as a stress signal in the $\mathrm{N}-\mathrm{NH}_{4}{ }^{+}$-treated plants.

Several studies have suggested that $\mathrm{NH}_{4}{ }^{+}$nutrition induces a stress response in several species (Lasa et al., 2001). Here, we confirmed that $\mathrm{N}_{-}-\mathrm{NH}_{4}{ }^{+}$treatment enhance resistance to salt stress. Moreover, it also found that $\mathrm{N}^{-\mathrm{NH}_{4}}{ }^{+}$treatment induced a similar phenotypical response to the recently stress-induced morphogenetic response (SIMRs) (Potters et al., 2007, 2009). We hypothesize that $\mathrm{N}-\mathrm{NH}_{4}{ }^{+}$treatment triggers mild chronic stress in citrange Carrizo plants which may account for the SIMRs noted. SIMRs is part of a general acclimation strategy characterized by blockage of cell division in main meristematic tissues, inhibition of elongation, redirected outgrowth of lateral organs (Potters et al., 2009), increase in 
antioxidants that prevent damage caused by ROS, and accumulation of foliar molecules which act as modulators of stress signals (Gould and Lister, 2006). This work demonstrates that the $\mathrm{N}-\mathrm{NH}_{4}{ }^{+}$-treated plants clearly provoke an increase in lateral organs by augmenting the weight and number of lateral roots. $\mathrm{N}_{-} \mathrm{NH}_{4}{ }^{+}$plants do not increase primary root length, however these plants showed an increase of modulators of stress signaling, such as $\mathrm{H}_{2} \mathrm{O}_{2}$, which could be intermediated between stress and the development of the SIMRs phenotype (Potters et al., 2007). This observation suggests that $\mathrm{NH}_{4}{ }^{+}$treatment results in an enhanced resistance to salinity, possibly due to plants being previously exposed to mild stress which could be the prime citrange Carrizo defenses by stress imprinting, thus conferring plants resistance (Bruce et al., 2007).

On the one hand, we also investigated the effect of $\mathrm{NH}_{4}{ }^{+}$nutrition on the expression of the $R D 22, P R 5$, and $A O S$ marker genes involved in the stress response. We noted that $\mathrm{N}^{-\mathrm{NH}_{4}}{ }^{+}$ treatment increase the accumulation of the three marker genes. These results may indicate that the $\mathrm{N}-\mathrm{NH}_{4}{ }^{+}$plants have a more active defense pathway than the control plants. Moreover, salt treatment mainly increased $P R 5$ accumulation in the control plants, but the expression of the other marker genes in the control and the $\mathrm{N}_{-} \mathrm{NH}_{4}{ }^{+}$plants was practically unaffected, which may be directly due to acclimated stage that $\mathrm{NH}_{4}{ }^{+}$nutrition confers to citrus plants.

The analysis of hormones and metabolites in relation to plant responses to salinity reveal that ABA plays a role in the response against salt stress in the $\mathrm{N}-\mathrm{NH}_{4}{ }^{+}$plants. In this work, we found that the $\mathrm{N}^{-\mathrm{NH}_{4}}{ }^{+}$plants have higher ABA levels than the control plants in the absence of salt. This fact is supported by the findings of Lopes and Araus (2008), who studied the gene expression profiles of barley seedlings fertilized with $\mathrm{NH}_{4}{ }^{+}, \mathrm{NH}_{4}{ }^{+}$and $\mathrm{NO}_{3}{ }^{-}$, or with $\mathrm{NO}_{3}{ }^{-}$ they observed that an epoxycarotenoid dioxygenase gene (involved to ABA synthesis) was upregulated in $\mathrm{NH}_{4}{ }^{+}$, probably due to $\mathrm{NH}_{4}{ }^{+}$treatments which may invoke stress responses. Previous results have shown that stomatal closure occurs when barley plants are exposed to 
$\mathrm{NH}_{4}{ }^{+}$for long periods. The fact that $\mathrm{NH}_{4}{ }^{+}$nutrition increases $\mathrm{ABA}$ accumulation in leaves may induce ABA-signaling. ABA signaling plays an important role in adaptation to abiotic stress and in the regulation of several genes, thought to be involved in dehydratation or salt tolerance as well as in stomatal closure (Zhu 2002). However, signaling in response to salinity seems to not depend solely on ABA. SA has long since been known to be a signal molecule in inducing defense mechanisms in plants (Shah 2003, Halim et al., 2007). Under our experimental conditions, the control plants exhibit SA accumulation at $14 \mathrm{~d}$ after salt stress; this accumulation correlates well with the SA-marker gene, $P R 5$, since it was overexpressed in the control plants at the same time. On the other hand, several studies support that SA binds directly to the catalase enzymes inhibiting its activity in several plants species (Sanchez-Casas and Klessig, 1994; Horvath et al., 2002). This inhibition of catalase activity has been proposed to explain an increased $\mathrm{H}_{2} \mathrm{O}_{2}$ level upon SA accumulation (Chen et al., 1993), and $\mathrm{H}_{2} \mathrm{O}_{2}$ is responsible for ROS accumulation and induction of cell death (Overmyer et al., 2003). This fact can explain our results since the control plants, with greater SA accumulation, were more affected by salinity. Jackab et al. (2005) observed that BABAinduced salt stress tolerance mediated by ABA-dependent signaling in Arabidopsis and this response is independent of functional SA signaling. In this work, we also show antagonism between $\mathrm{ABA}$ and $\mathrm{SA}$ since the $\mathrm{N}_{-} \mathrm{NH}_{4}{ }^{+}$plants treated with $\mathrm{NaCl}$ showed a faster, stronger ABA accumulation which could inhibit SA accumulation. Hence, salinity resistance in the N$\mathrm{NH}_{4}{ }^{+}$plants might be mediated by ABA accumulation, which is a regulator of salt tolerance. $\mathrm{N}-\mathrm{NH}_{4}{ }^{+}$treatment could increase ABA accumulation in leaves, thus conferring citrange Carrizo plants resistance to later salinity conditions.

The analysis of PAs in our study has determined that $\mathrm{N}^{-\mathrm{NH}_{4}}{ }^{+}$treatment induces a faster, stronger Put accumulation at $2 \mathrm{~h}$ (data not shown) and at $14 \mathrm{~d}$ in the absence of salt. It is commonly accepted that some species develop toxic symptoms when $\mathrm{NH}_{4}{ }^{+}$nutrition is 
applied (Gerendás et al., 1997; Lasa et al., 2001), while a negative effect on plant growth has been observed with this kind of nutrition (Claussen and Lenz, 1999; Walch-Liu et al., 2000). Ammonium nutrition decreases essential cations content (Britto and Kronzucker, 2002), probably due to competition with $\mathrm{NH}_{4}^{+}$in the uptake process. Although the uptake of cations other than $\mathrm{NH}_{4}{ }^{+}$is sometimes reduced, $\mathrm{NH}_{4}{ }^{+}$uptake usually increases under $\mathrm{NH}_{4}{ }^{+}$nutrition. Finally, plants may have excessive total cation content in comparison with anion content (Clark 1982). Gerendás et al. (1997) suggest that plants could accumulate PAs to compensate for the lack of some cations other than $\mathrm{NH}_{4}{ }^{+}$, hence they could contribute to cellular ionic balance maintenance. Furthermore PAs mainly Put, has an important role in abiotic stress since it reduces salt-induced oxidative damage by increasing the activities of antioxidant enzymes and by lowering lipid peroxidation (Tang and Newton, 2005). In this work, we also reveal that $\mathrm{NH}_{4}{ }^{+}$treatment leads to a greater induction of gene PHGPx. PHGPx is a unique intracellular antioxidant enzyme that directly reduces the phospholipid hydroperoxides produced in cell membranes, and has been considered the main line of enzymatic defense against oxidative biomembrane damage in mammalian cells (Chun-Juan et al., 2009). Furthermore, $P H G P x$ gene expression levels have been recorded to increase in plant tissues in response to pathogen infections (Criqui et al., 1992), high salinity (Li et al., 2001), heavy metals (Li et al., 2001), and extreme temperatures (Chen et al., 2004), suggesting the important roles that play in the defense responses of plants to biotic and abiotic stresses. Transient expression of LePHGPx protects tobacco leaves from salt and heat stress, and suppresses the apoptotic pathway induced by Bax (Chen et al., 2004). Our results suggest that the resistance to salinity that we found in the $\mathrm{N}_{-} \mathrm{NH}_{4}{ }^{+}$-treated plants could be mediated by a stronger accumulation of Put and the PHGPx transcript, which might induce resistance to the oxidative damage induced by salinity. 
In conclusion, collectively these results indicate that $\mathrm{NH}_{4}{ }^{+}$treatment enhances citrange Carrizo defense against salinity stress. This suggests that $\mathrm{NH}_{4}{ }^{+}$treatment produces mild chronic stress and therefore induces the SIMRs in citrange Carrizo. Activation of the response related to SIMRs due to $\mathrm{NH}_{4}{ }^{+}$toxicity led to the "acclimation stage", which leads to better adaptation to subsequent salt stress. This response initially brings about increased $\mathrm{H}_{2} \mathrm{O}_{2}$ accumulation which could act as a modulator of stress signal. Besides this, $\mathrm{NH}_{4}{ }^{+}$treatment lowers $\mathrm{Cl}^{-}$accumulation in leaves reducing its toxic effect and produces a higher basal proline content which might confer initial protection against salt stress. Moreover, the $\mathrm{N}_{-} \mathrm{NH}_{4}{ }^{+}$treated plants have more active defense pathways than the control plants, and have activated ABA accumulation, which could prime ABA-signaling and PAs, mainly Put, which, in turn, could contribute to cellular ionic balance maintenance and reduce salt-induced oxidative damage. Furthermore, the $\mathrm{N}_{-} \mathrm{NH}_{4}{ }^{+}$citrus seedlings display enhanced antioxidant machine activity, thus increasing PHGPx transcription. Together, this observation suggests that $\mathrm{NH}_{4}{ }^{+}$treatments induce a mild stress condition that primes the citrange Carrizo defense response by stress imprinting and confers protection against a subsequent salt stress. The use of nutritional compounds like $\mathrm{NH}_{4}{ }^{+}$could be an interesting alternative to the use of chemical compounds to induce plant resistance. In addition, this fact may help to alleviate the toxicity caused by salinity, one of the major problems currently on citrus crop.

\section{ACKNOWLEDGEMENTS}

This work was supported by the National R\&D Plan (AGL2010-22300-C03-01 and AGL2010-22300-C03-02). The authors are grateful to the SCIC at the Universitat Jaume I.

\section{REFERENCES}

Al-Yassin A. Review: adverse effects of salinity on citrus. Int J Agric Biol 2005; 7:668-680 
Bagh K, Hiraoki T, Thorpe TA, Vogel HJ. Nitrogen-15 NMR studies of nitrogen metabolism in Picea glauca buds. Plant Physiol Biochem 2004; 42:803-809

Bañuls J, Primo-Millo E. Effects of chloride and sodium on gas exchange parameters and water relations of Citrus plants. Physiol Plant 1992; 86: 115-123

Bartels D, Sunkar R. Drought and salt tolerance in plants. Crit Rev Plant Sci 2005; 24: 23-58

Bates LS, Waldren RP, Teare ID. Rapid determination of free proline in eater stress studies. Plant Soil 1973; 39: 205-208

Britto DT, Siddiqi MY, Glass ADM, Kronzucker HJ. Futile transmembrane $\mathrm{NH}_{4}{ }^{+}$cycling: a cellular hypothesis to explain ammonium toxicity in plants. Proc Natl Acad Sci USA 2001; 98: $4255-4258$

Britto DT, Kronzucker H. $\mathrm{NH}_{4}{ }^{+}$toxicity in higher plants: a critical review. J Plant Physiol $2002 ; 159: 567-84$

Bruce JA, Matthes MC, Napier JA, Pickett JA. Stressful 'memories' of plants: evidence and possible mechanisms. Plant Sci 2007; 173:603-608

Brumós J, Colmenero-Flores JM, Conesa A, Izquierdo P, Sánchez G, Iglesias DJ, LópezCliment MF, Gómez-Cadenas A, Talón M. Membrane transporters and carbon metabolism implicated in chloride homeostasis differentiate salt stress responses in tolerant and sensitive Citrus rootstocks. Funct Integr Genomics 2009; 9(3):293-309

Camañes G, Cerezo M, Primo-Millo E, Alan G, García-Agustín P. Ammonium transport and CitAMT1 expression are regulted by N in Citrus plants. Planta 2009; 229:331-342

Chattopadhayay MK, Tiwari BS, Chattopadhayay G, Bose A, Sengupta DN, Ghosh B. Protective role of exogenous polyamines on salinity-stressed rice (Oryza sativa) plants. Physiol Plant 2002; 116: 192-199

Chen C, Dickman, MB. Proline suppresses apoptosis in the fungal pathogen Colletotrichum trifolii. Proc Natl Acad Sci 2005; 102: 3459-3464 
Chen S, Vaghchhipawala Z, Li W, Asard H, Dickman MB. Tomato phospholipid hydroperoxide glutathione peroxidase inhibits cell death induced by Bax and oxidative stresses in yeast and plants. Plant Physiol 2004; 135:1630-1641

Chen Z, Silva H, Klessig RF. Active oxygen species in the induction of plant systemic acquired resistance by SA. Science $1993 ; 262: 1883-1886$

Chun-Juan D, Xiao-Dong Y, Jin-Yuan L. Enzymatic properties of a recombinant phospholipid hydroperoxide glutathione peroxidase from Momordica charantia and its complementation function in yeast. Biochem 2009; 74: 502-508

Clark RB. Nutrient solution growth of sorghum and corn in mineral nutrition studies. J Plant Nutr 1982; 5:1039-57

Claussen W, Lenz F. Effect of ammonium or nitrate nutrition on net photosynthesis, growth, and activity of the enzymes nitrate reductase and glutamine synthetase in blueberry, raspberry and strawberry. Plant Soil 1999; 208:95-102

Conrath U, Pieterse CMJ, Mauch-Mani, B. Priming in plant-pathogen interactions. Trends Plant Sci. 2002; 7:210-216

Conrath U, Beckers GJM, Flors V, Garcia-Agustin P, Jakab G, Mauch F, Newman MA, Pieterse C, Poinssot B, Pozo MJ, Pugin A, Schaffrath U, Ton J, Wendehenne D, Zimmerli L, Mauch-Mani B. Priming: getting ready for battle. Mol Plant-Microbe Interact 2006; 19:106271

Coruzzi G, Bush DR. Nitrogen and carbon nutrient and metabolite signalling in plants. Plant Physiol 2001; 125: 61-64 
Criqui MC, Jamet E, Parmentier Y, Marbach J, Durr A, Fleck J. Isolation and characterization of a plant cDNA showing homology to animal glutathione peroxidases. Plant Mol Biol 1992; $18: 623-627$

Dat J, Vandenabeele S, Vranova E, Van Montagu M, Inzé D, Van Breusegem F. Dual action of active oxygen species during plant stress responses. Cell Mol Life Sci 2000; 57: 779-795 Ellouzi H, Hamed KB, Cela J, Munné-Bosch S, Abdelly C. Early effects of salt stress on the physiological and oxidative status of Cakile maritime (halophyte) and Arabidopsis thaliana (glycophyte). Physiol Plant 2011; 142:128-143

Flors V, Leyva MD, Vicedo B, Finiti I, Real MD, García-Agustín P. Absence of the endobeta-1,4-glucanases Cel1 and Cel2 reduces susceptibility to Botrytis cinerea in tomato. Plant J $2007 ; 52: 1027-40$

Flors V, Ton J, van Doorn R, Jakab G, García-Agustín P, Mauch-Mani B. Interplay between JA, SA and ABA signaling during basal and induced resistance against Pseudomonas syringae and Alternaria brassicicola. Plant J 2008; 54: 81-92

Foyer CH, López-Delgado H, Dat JF, Scott IM. Hydrogen peroxide- and glutathioneassociated mechanisms of acclimatory stress tolerance and signaling. Physiol Plant 1997;100: $241-254$

Foyer $\mathrm{CH}$, Noctor G. Oxidant and antioxidant signalling in plants: a re-evaluation of the concept of oxidative stress in a physiological context. Plant Cell Environ 2005; 28: 10561071

Galis I, Gaquerel E, Pandey SP, Baldwin IT. Molecular mechanisms underlying plant memory in JA-mediated defence responses. Plant Cell Environ 2009; 38:617-627 Gaspar T, Frank T, Bisbis B, Kevers C, Jouve L, Hausman JF, Dommes J. Concepts in plant stress physiology. Application to plant tissue cultures. Plant Growth Regul 2002; 37: 263-285 
Gerendás J, Zhu Z, Bendixen R, Ratcliffe RG, Sattelmacher B. Physiological and biochemical processes related to ammonium toxicity in higher plants. Z Pflanzernähr Bodenkd 1997; $160: 239-51$

Gould KS, Lister C. Flavonoid functions in plants. In: Andersen OslashM, Markham KR, eds. Flavonoids: chemistry, biochemistry, and applications. Boca Raton: CRC Press 2006: 397441

Groppa MD, Tomaro ML, Benavides MP. Polyamines as protectors against cadmium or copper-induced oxidative damage in sunflower leaf discs. Plant Sci 2001; 161: 481-488 Groppa MD, Benavides MP. Polyamines and abiotic stress: recent advances. Amino Acids $2008 ; 34: 35-45$

Halim V, Eschen-Lippold L, Altmann S, Birschwilks M, Scheel D, and Rosahl S. Salicylic acid is important for basal defense of Solanum tuberosum against Phytophthora infestans. Mol Plant-Microbe Interact 2007; 11:1346-1352

Hernandez JA, Almansa MS. Short-term effects of salt stress on antioxidant systems and leaf water relations of pea leaves. Physiol Plant 2002; 115: 251-257

Hoagland DR, Arnon DJ. The water culture method for growing plants without soil. Calif Agr Expt Sta Circ 1950; 347: 1-32

Horvath E, Janda T, Szalai G, Paldi E. In vitro salicylic acid inhibition of catalase activity in maize: differences between the isozymes and a possible role in the induction of chilling tolerance. Plant Sci 2002; 163:1129-1135

Jakab G, Ton J, Flors V, Zimmerli L, Metraux P, Mauch-Mani B. Enhancing Arabidopsis Salt and Drought Stress Tolerance by Chemical Priming for Its Abscisic Acid Responses. Plant Physiol 2005; 139: 267-274

Jones DL, Kochian LV. Aluminum inhibition of the 1,4,5-trisphosphate signal transduction pathway in wheat roots: a role in aluminum toxicity? The Plant Cell 1995; 7: 1913-1922 
Jubany-Marí T, Munné-Bosch S, López-Carbonell M, Alegre L. Hydrogen peroxide is involved in the acclimation of the Mediterranean shrub, Cistus albidus L., to summer drought. J Exp Bot 2009; 60: 107-120

Kakkar RK and Sawhney VK. Polyamine research in plants - a changing perspective. Physiol Plant 2003; 116: 281-292

Kishor PB, Sangam S, Amrutha RN, Sri Laxmi P, Naidu KR, Rao KRSS, Sreenath Rao, Reddy KJ, Theriappan P, Sreenivasulu N. Regulation of proline biosynthesis, degradation, uptake and transport in higher plants: its implications in plant growth and abiotic stress tolerance. Curr Sci 2005; 88: 424-438

Kravchuk Z, Vicedo B, Flors V, Camañes G, González-Bosch C, García-Agustín P. Priming for JA-dependent defenses using hexanoic acid is an effective mechanism to protect Arabidopsis against B. cinerea. J Plant Physiol 2011; 168 359-366

Lasa B, Frechilla S, Lamsfus C, Aparicio-Tejo PM. The sensitivity to ammonium nutrition is related to nitrogen accumulation. Sci Hort 2001; 91:143-152.

Li Q, Li BH, Kronzucker HJ, Shi WM. Root growth inhibition by $\mathrm{NH}_{4}{ }^{+}$in Arabidopsis is mediatedby the root tip and is linked to $\mathrm{NH}_{4}{ }^{+}$efflux and GMPase activity. Plant Cell Environ 2010; 34(6):933-946

Li W, Liu JY, Zhao N. Cloning and characterization of phospholipid hydroperoxide glutathione peroxidase gene from Momordica charantia. Prog Biochem Biophys 2001; 28:908-911

Lopes MS, Araus JL. Comparative genomic and physiological analysis of nutrient response to $\mathrm{NH}_{4}{ }^{+}, \mathrm{NH}_{4}{ }^{+}: \mathrm{NO}_{3}{ }^{-}$and $\mathrm{NO}_{3}{ }^{-}$in barley seedlings. Physiol Plant 2008; 134:134-150 Lopez-Climent M, Arbona V, Perez-Clemente RM, Gomez-Cadenas A. Relationship between salt tolerance and photosynthetic machinery performance in citrus. Environ Exp Bot 2008; 62: 176-184. 
Macarisin D, Wisniewski ME, Bassett C, Thannhauser T. Proteomic analysis of baminobutyric acid priming and abscisic acid - induction of drought resistance in crabapple (Malus pumila): effect on general metabolism, the phenylpropanoid pathway and cell wall enzymes. Plant Cell Environ 2009; 32: 1612-1631

Marschner H () Mineral Nutrition of Higher Plants. Academic Press, London 1995; 2nd Edn. Mittler R () Oxidative stress, antioxidants and stress tolerance. Trends Plant Sci 2002; 7: 405410

Munns R, Tester M. Mechanism of salinity tolerance. Annu Rev Plant Biol 2008; 59:651-81 Nylander M, Svensson J, Palva ET, Welin BV. Stress-induced accumulation and tissuespecific localization of dehydrins in Arabidopsis thaliana. Plant Mol Biol 2001; 45:263-279 Oostendorp M, Kunz W, Dietrich B, Staub T. Induced disease resistance in plants by chemicals. Eur J Plant Pathol 2001; 107:19-28

Overmyer K, Brosché M, Kangasjärvi J. Reactive oxygen species and hormonal control of cell death. Trends Plant Sci 2003; 8: 335-342

Pedranzani H, Racagni G, Alemano S, Miersch O, Ramírez I, Peña-Cortés H, Taleisnik E, Machado-Domenech E, Abdala G. Salt tolerant tomato plants show increased levels of jasmonic acid. Plant Growth Regul 2003; 41: 149-158

Potters G, Pasternak TP, Guisez Y, Palme KJ, Jansen MAK. Stress-induced morphogenic responses: growing out of trouble? Trends Plant Sci 2007; 12: 98-105

Potters G, Pasternak TP, Guisez Y, Jansen MA. Different stresses, similar morphogenic responses: integrating a plethora of pathways. Plant Cell Environ 2009; 32:158-169 Ravindran KC, Venkatesa K, Balakrishan V, Chellappan KP, Balasubramanian T. Restoration of saline land by halophytes for Indian soils. Soil Biol Biochem 2007; 39:2661-2664 
Romero-Aranda R, Moya JL, Tadeo FR, Legaz F, Primo-Millo E, Talon M. Physiological and anatomical disturbances induced by chloride salts in sensitive and tolerant citrus: beneficial and detrimental effects of cations. Plant Cell Environ. 1998; 21:1243-1253

Sakamoto M, Munemura I, Tomita R, Kobayashi K. Involvement of hydrogen peroxide in leaf abscission signaling, revealed by analysis with an in vitro abscission system in Capsicum plants. Plant J 2008; 56: 13-27

Sanchez-Casas P, Klessig DF. A salicylic acid-binding activity and a salicylic acid-inhibitable catalase activity are present in a variety of plant species. Plant Physiol 1994; 106: 1675-1679 Sánchez-López J, Camañes G, Flors V, Cristian Barrera V, Vicedo B, Cerezo M, Pastor V, García-Agustín P. Underivatized polyamine analysis in plant samples by ion-pair LC coupled with electrospray tandem mass spectrometry. Plant Physiol Biochem 2009; 47:592-598

Shah J. The salicylic acid loop in plant defense. Curr Opin Plant Biol 2003; 6:365-371 Svistoonoff S, Creff A, Reymond M, Sigoillot-Claude C, Ricaud L, Blanchet A, Nussaume L, Desnos T. Root tip contact with low-phosphate media reprograms plant root architecture. Nature Genetics 2007; 39:792-796

Szabados L, Savouré A. Proline: a multifunctional amino acid. Trends in Plant Sci 2009; 15(2):89-97

Tang W, Newton RJ. Polyamines reduce salt-induced oxidative damage by increasing the activities of antioxidant enzymes and decreasing lipid peroxidation in Virginia pine. Plant Growth Regul 2005; 46: 31-43

Thordal-Christensen H, Zang Z, Wei Y, Colling DB. Subcellular localisation of $\mathrm{H}_{2} \mathrm{O}_{2}$ in plants. $\mathrm{H}_{2} \mathrm{O}_{2}$ accumulation in papillae and hypersensitive response during the barley-powdery mildew interaction. Plant J 1997; 11: 1187-1194 
Van der Ent S, Van Hulten M, Pozo MJ, Czechowski T, Udvardi MK, Pieterse CM, Ton J. Priming of plant innate immunity by rhizobacteria and beta-aminobutyric acid: differences and similarities in regulation. New Phytol 2009; 183: 419-431

Vicedo B, Flors V, Leyva MD, Finiti I, Kravchuk Z, Real MD, García-Agustín P, González Bosch C. Hexanoic acid-induced resistance against Botrytis cinerea in tomato plants. Mol Plant-Microbe Interact 2009; 22:1455-1465

Walch-Liu P, Neumann G, Bangerth F, Engels C. Rapid effects of nitrogen form on leaf morphogenesis in tobacco. J Exp Bot 2000; 51:227-37

Wang MY, Siddiqi MY, Ruth TJ, Glass ADM. Ammonium uptake by rice roots. I. Fluxes and subcellular distribution of ${ }^{13} \mathrm{NH}_{4}{ }^{+}$. Plant Physiol 1993; 103:1249-1258

Yang N, Zhu C, Gan L, Denny Ng, Xia K. Ammonium-stimulated root hair branching is enhanced by methyl jasmonate and suppressed by ethylene in Arabidopsis thaliana. J Plant Biol 2011; 54(2): 92-100

Zhu B, Chen TH, Li PH. Expression of three osmotin-like protein genes in response to osmotic stress and fungal infection in potato. Plant Mol Biol 1995; 28: 17-26

Zhu B, Su J, Chong M, Verma DPS, Fare Y, Wu R. Overexpression of D-pyrolline-5carboxylate synthetase gene and analysis of tolerance to water- and salt stress in transgenic rice. Plant Sci 1998; 139: 41-48

Zhu JK. Salt and drought stress signal transduction in plants. Annual Review of Plant Biology 2002; 53: 247-273 
Table 1. Primers sequences

\begin{tabular}{|c|c|c|}
\hline Primer name & Forward primer & Reverse primer \\
\hline$G A P D H$ & $5^{\prime}$ - ggaaggtcaagatcggaatcaa - 3' & $5^{\prime}$ cgtccetctgcaagatgactct $-3^{\prime}$ \\
\hline$A O S$ & 5'- cgaatttcaatccccaagaa-3' & $5^{\prime}$ - ttggtgggttgttcatcaga-3' \\
\hline$P H G P x$ & $5^{\prime}$ - catcacagtgtggcttgacc $-3^{\prime}$ & $5^{\prime}-$ tgctggatttcagatgcttg $-3^{\prime}$ \\
\hline PR5 & $5^{\prime}$ - tgggggactactccaatgtc $-3^{\prime}$ & $5^{\prime}$ - atcctcctggaaccctcaat- $3^{\prime}$ \\
\hline$R D 22$ & $5^{\prime}$ - ttggaaaaggacttgcatcc-3' & $5^{\prime}-$ atgccagcgtcttcacactc- $3^{\prime}$ \\
\hline
\end{tabular}

Table 2. Polyamine levels expressed in $\mu \mathrm{g} \mathrm{g}^{-1} \mathrm{FW}$ in control and $\mathrm{N}-\mathrm{NH}_{4}{ }^{+}$plants upon salinity. Leaves were collected at 14 days after addition of $\mathrm{NaCl}(90 \mathrm{mM})$. Levels were determined in freeze-dried material by HPLC-MS. Data show the average of three independent experiments of a pool of 30 plants per experiment \pm SE. Letters indicates statistically significant differences $(p<0.05)$.

\begin{tabular}{llllllll}
\hline & Put & & Spd & & Spm & \\
\hline Control & $6.16 \pm 1.9$ & a & $29.51 \pm 1.41$ & b/c & $11.76 \pm 2.57$ & $\mathrm{a}$ \\
$\mathbf{N H}_{4}{ }^{+}$ & $146.98 \pm 27.87$ & b & $36.06 \pm 1.93$ & c & $19.83 \pm 2.36$ & $\mathrm{~b}$ \\
\hline Control + NaCl & $3.04 \pm 1.12$ & a & $24.35 \pm 2.99$ & $\mathrm{a} / \mathrm{b}$ & $12.89 \pm 2.61$ & $\mathrm{a}$ \\
$\mathbf{N H}_{\mathbf{4}}{ }^{+}+\mathbf{N a C l}$ & $160 \pm 14.68$ & $\mathrm{~b}$ & $30.65 \pm 3.43$ & $\mathrm{~b} / \mathrm{c}$ & $18.77 \pm 4.02$ & $\mathrm{a}$ \\
\hline
\end{tabular}

\section{FIGURE LEGENDS}

Fig. 1. Effect of $\mathrm{NH}_{4}{ }^{+}$nutrition on the growth of citrange Carrizo plants. (A) Biomass production, (B) root length, $(\mathrm{C})$ root DW, lateral roots development expressed as: (D) number 
of lateral roots/root DW and (E) number of lateral roots/root length. Data are from a representative experiment that was repeated three times with similar results. Values are the mean of 50 seedlings. Asterisk indicates statistically significant differences $(p<0.05)$.

Fig. 2. Effect of $\mathrm{NH}_{4}{ }^{+}$treatment on the citrange Carrizo plants treated with $\mathrm{NaCl}(90 \mathrm{mM})$ for $14 \mathrm{~d}$. The result is expressed as \% of damage at different levels: healthy leaves, chlorotic leaves (level 1), intermediate leaf necrosis (level 2) and burnt leaves (level 3). Data are from a representative experiment that was repeated three times with similar results. Values are the mean of 50 seedlings.

Fig. 3. Effect of $\mathrm{NH}_{4}{ }^{+}$treatment on the $\mathrm{Cl}^{-}$and proline content in the citrange Carrizo plants treated with $\mathrm{NaCl}(90 \mathrm{mM})$ for $2 \mathrm{~h}$ and $14 \mathrm{~d}$. (A) $\mathrm{Cl}^{-}$content expressed in $\mathrm{mg} \mathrm{Cl}^{-} \mathrm{g}^{-1} \mathrm{DW}$ and (B) Proline accumulation expressed in $\mu$ mol proline $\mathrm{g}^{-1} \mathrm{FW}$. Data show the average of three independent experiments of a pool of 30 plants \pm SE. Letters indicate statistically significant differences $(p<0.05)$.

Fig. 4. $\mathrm{H}_{2} \mathrm{O}_{2}$ staining, estimated by using DAB staining in the leaves of the control and the N$\mathrm{NH}_{4}^{+}$citrange Carrizo treated with $\mathrm{NaCl}(90 \mathrm{mM})$ for $2 \mathrm{~h}$. (A) Quantitative $\mathrm{H}_{2} \mathrm{O}_{2}$ measurement on the basis of brown pixels from digital photographs and (B) Brownish areas are indicative of $\mathrm{H}_{2} \mathrm{O}_{2}$ accumulation. Data are from a representative experiment that was repeated three times with similar results. Values are the mean of 10 seedlings. Letters indicates statistically significant differences $(\mathrm{p}<0.05)$.

Fig. 5. Hormone levels in the control and $\mathrm{N}_{-} \mathrm{NH}_{4}{ }^{+}$citrange Carrizo plants upon salinity. Leaves were collected at $14 \mathrm{~d}$ after addition of $\mathrm{NaCl}(90 \mathrm{mM})$. (A) ABA and (B) SA levels were determined in freeze-dried material by HPLC-MS. Data show the average of three 
independent experiments of a pool of 30 plants per experiment \pm SE. Asterisk indicates statistically significant differences $(\mathrm{p}<0.05)$.

Fig. 6. Effect of $\mathrm{NH}_{4}{ }^{+}$treatment on the gene expression in citrange Carrizo plants upon salt stress. Total RNA was isolated from leaves at $14 \mathrm{~d}$ after addition of $\mathrm{NaCl}(90 \mathrm{mM})$ converted into cDNA, and was subjected to a RT-qPCR analysis. The results were normalized to the GAPDH gene expression measured in the same samples. The relative level of (A) RD22, (B) $P R 5$ and (C) AOS were analyzed in the control and the $\mathrm{N}^{-\mathrm{NH}_{4}}{ }^{+}$citrus plants. The data show the average of three independent experiments obtained with a pool of 10 plants per point \pm SE. The experiment was repeated three times with similar results.

Fig. 7. Effect of $\mathrm{NH}_{4}{ }^{+}$treatment on the $P H G P x$ expression in the citrange Carrizo plants upon salt stress. Total RNA was isolated from leaves at $14 \mathrm{~d}$ after addition of $\mathrm{NaCl}(90 \mathrm{mM})$ converted into cDNA, and was subjected to a RT-qPCR analysis. The results were normalized to the GAPDH gene expression measured in the same samples. The data show the average of three independent experiments obtained with a pool of 10 plants per point \pm SE. The experiment was repeated three times with similar results. 


\section{FIGURES}
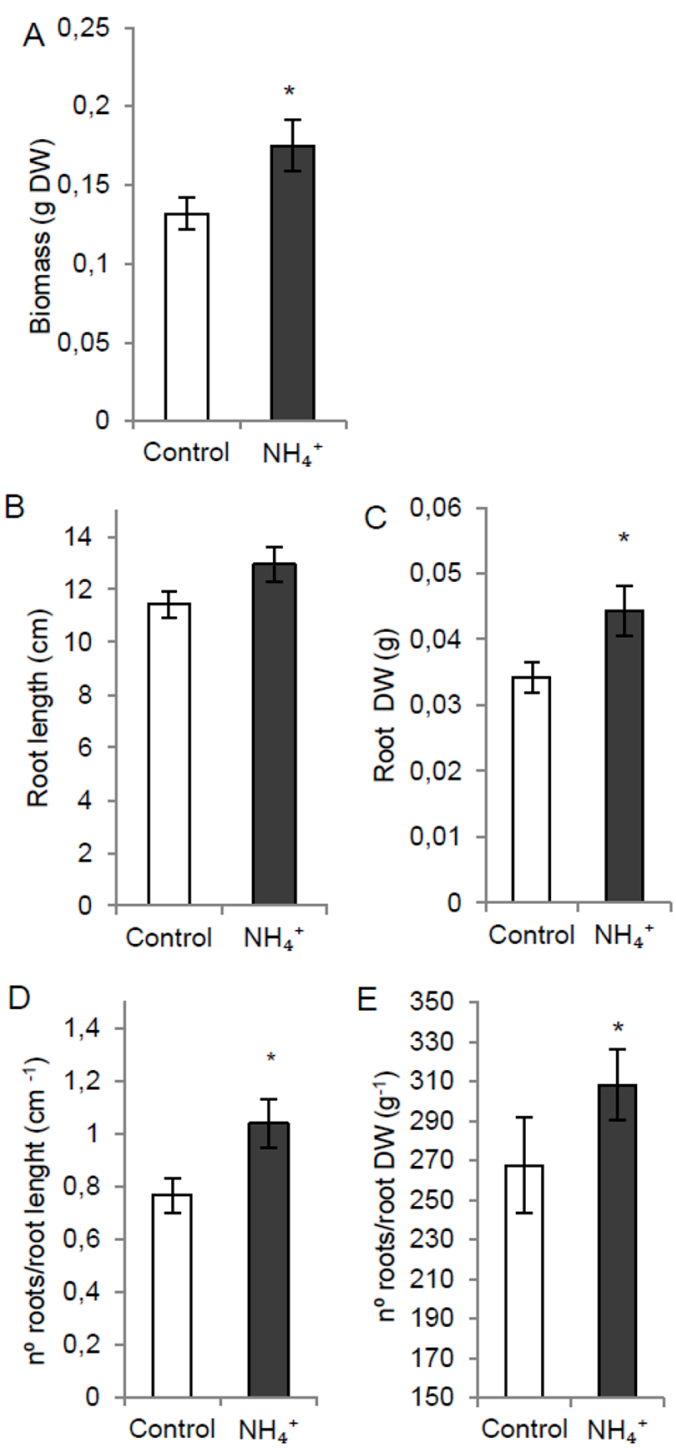

Fig. 1. Effect of $\mathrm{NH}_{4}{ }^{+}$nutrition on the growth of citrange Carrizo plants. (A) Biomass production, (B) root length, (C) root DW, lateral roots development expressed as: (D) number of lateral roots/root DW and (E) number of lateral roots/root length. Data are from a representative experiment that was repeated three times with similar results. Values are the mean of 50 seedlings. Asterisk indicates statistically significant differences $(p<0.05)$. 


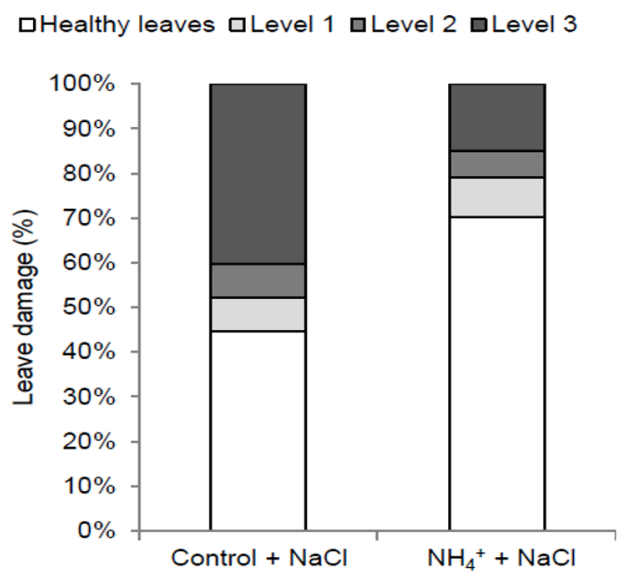

Fig. 2. Effect of $\mathrm{NH}_{4}{ }^{+}$treatment on the citrange Carrizo plants treated with $\mathrm{NaCl}(90 \mathrm{mM})$ for $14 \mathrm{~d}$. The result is expressed as \% of damage at different levels: healthy leaves, chlorotic leaves (level 1), intermediate leaf necrosis (level 2) and burnt leaves (level 3). Data are from a representative experiment that was repeated three times with similar results. Values are the mean of 50 seedlings. 
A

$\square 2 \mathrm{~h} \square 14 \mathrm{~d}$

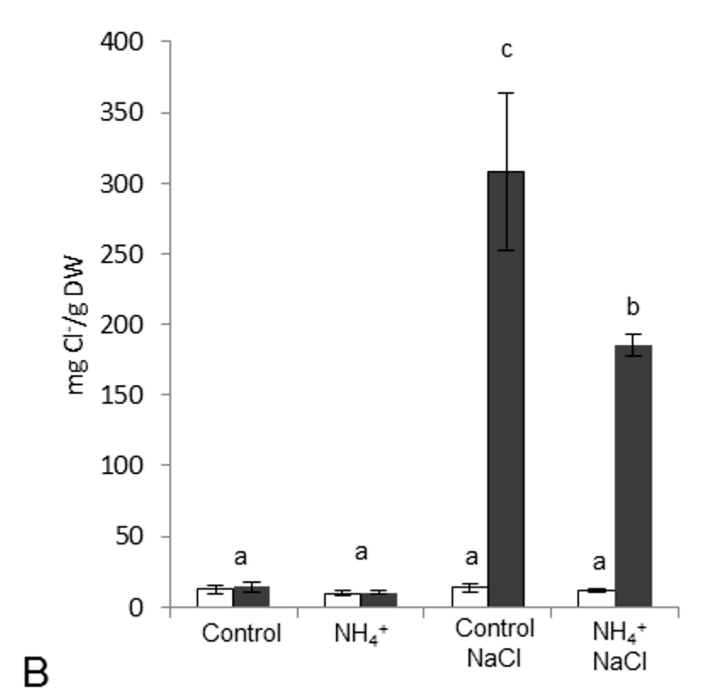

B

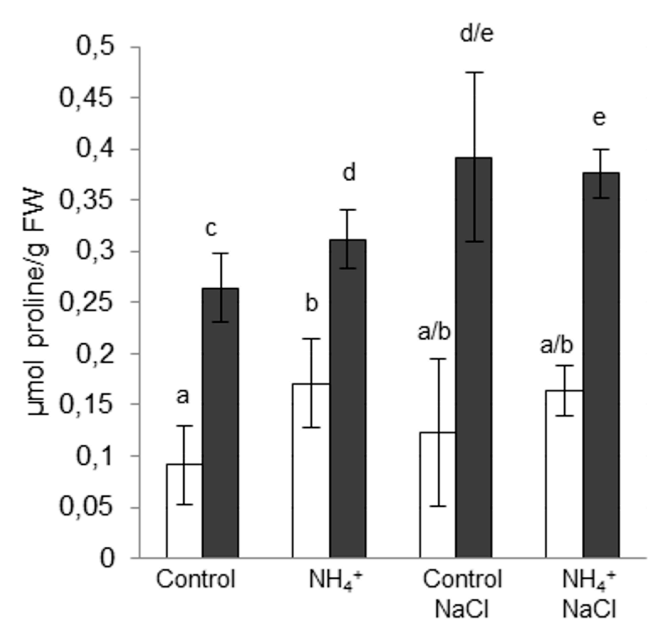

Fig. 3. Effect of $\mathrm{NH}_{4}{ }^{+}$treatment on the $\mathrm{Cl}^{-}$and proline content in the citrange Carrizo plants treated with $\mathrm{NaCl}(90 \mathrm{mM})$ for $2 \mathrm{~h}$ and $14 \mathrm{~d}$. (A) $\mathrm{Cl}^{-}$content expressed in $\mathrm{mg} \mathrm{Cl}^{-} \mathrm{g}^{-1} \mathrm{DW}$ and (B) Proline accumulation expressed in $\mu \mathrm{mol}$ proline $\mathrm{g}^{-1} \mathrm{FW}$. Data show the average of three independent experiments of a pool of 30 plants \pm SE. Letters indicate statistically significant differences $(p<0.05)$. 

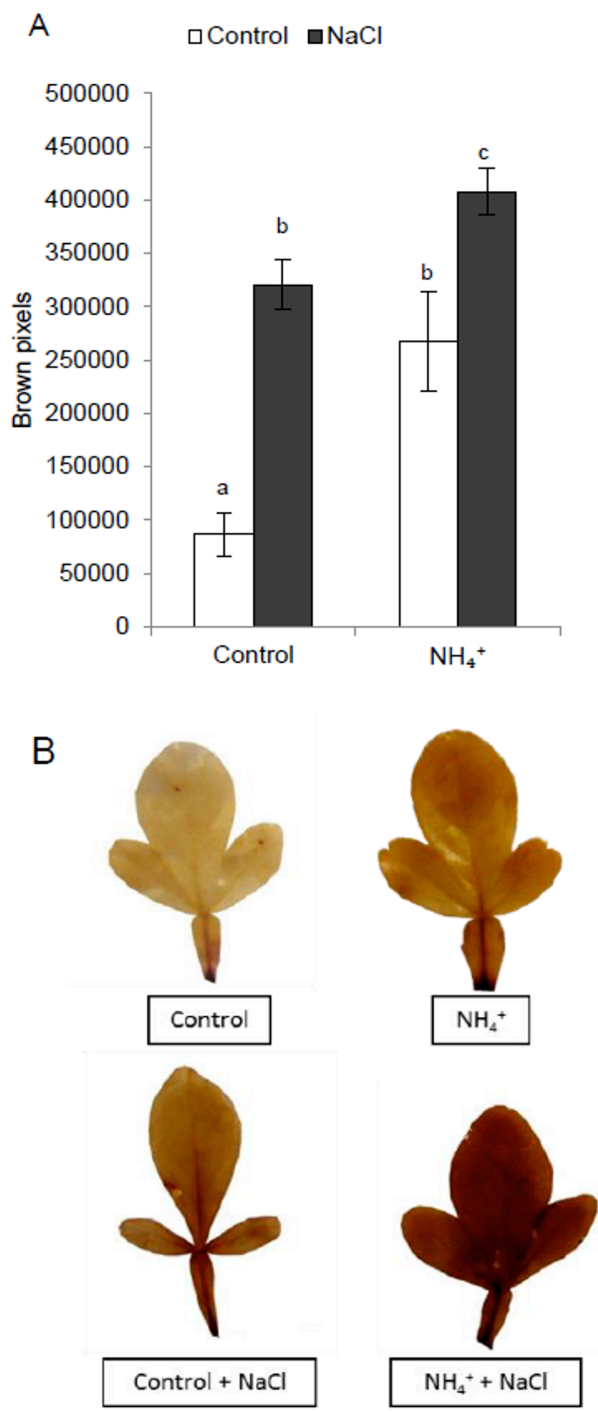

Fig. 4. $\mathrm{H}_{2} \mathrm{O}_{2}$ staining, estimated by using DAB staining in the leaves of the control and the N$\mathrm{NH}_{4}{ }^{+}$citrange Carrizo treated with $\mathrm{NaCl}(90 \mathrm{mM})$ for 2 h. (A) Quantitative $\mathrm{H}_{2} \mathrm{O}_{2}$ measurement on the basis of brown pixels from digital photographs and (B) Brownish areas are indicative of $\mathrm{H}_{2} \mathrm{O}_{2}$ accumulation. Data are from a representative experiment that was repeated three times with similar results. Values are the mean of 10 seedlings. Letters indicates statistically significant differences $(\mathrm{p}<0.05)$. 
$\square$ Control $\square \mathrm{NaCl}$
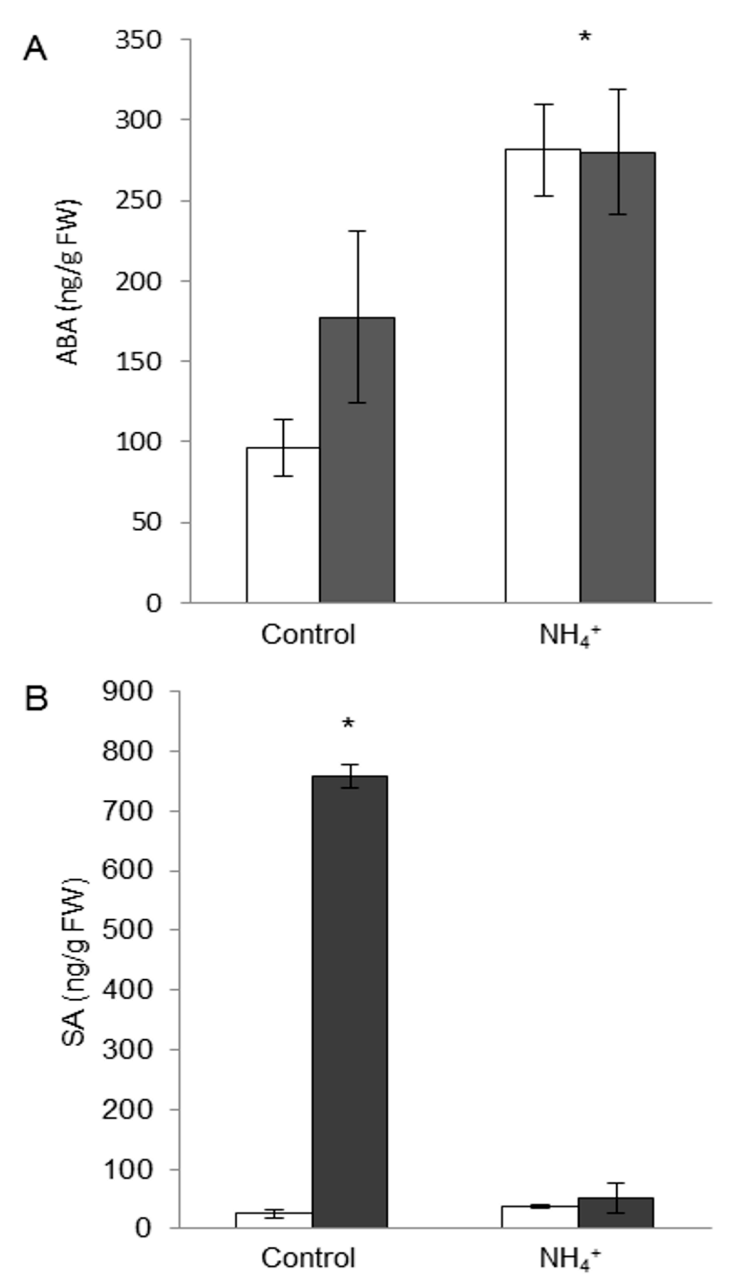

Fig. 5. Hormone levels in the control and $\mathrm{N}_{-} \mathrm{NH}_{4}{ }^{+}$citrange Carrizo plants upon salinity. Leaves were collected at $14 \mathrm{~d}$ after addition of $\mathrm{NaCl}(90 \mathrm{mM})$. (A) ABA and (B) SA levels were determined in freeze-dried material by HPLC-MS. Data show the average of three independent experiments of a pool of 30 plants per experiment \pm SE. Asterisk indicates 


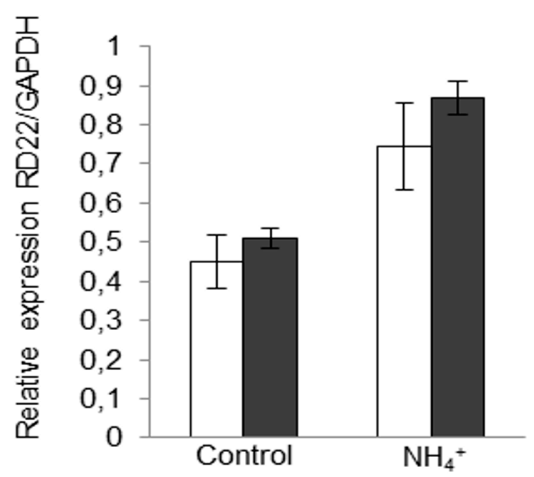

B
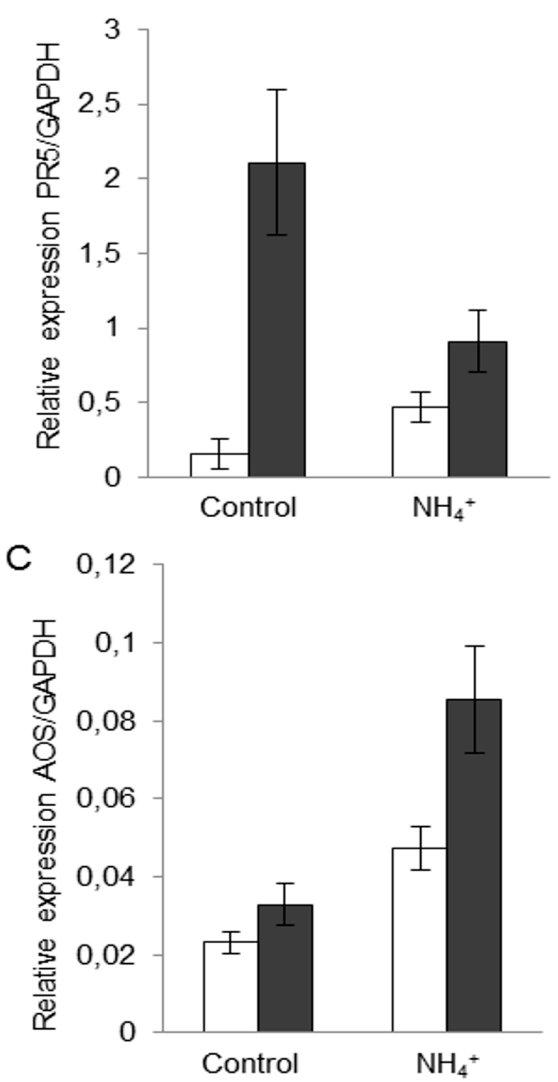

Fig. 6. Effect of $\mathrm{NH}_{4}{ }^{+}$treatment on the gene expression in citrange Carrizo plants upon salt stress. Total RNA was isolated from leaves at $14 \mathrm{~d}$ after addition of $\mathrm{NaCl}(90 \mathrm{mM})$ converted into cDNA, and was subjected to a RT-qPCR analysis. The results were normalized to the $G A P D H$ gene expression measured in the same samples. The relative level of (A) $R D 22,(\mathrm{~B})$ PR5 and (C) AOS were analyzed in the control and the $\mathrm{N}_{-} \mathrm{NH}_{4}{ }^{+}$citrus plants. The data show 
the average of three independent experiments obtained with a pool of 10 plants per point $\pm \mathrm{SE}$. The experiment was repeated three times with similar results.

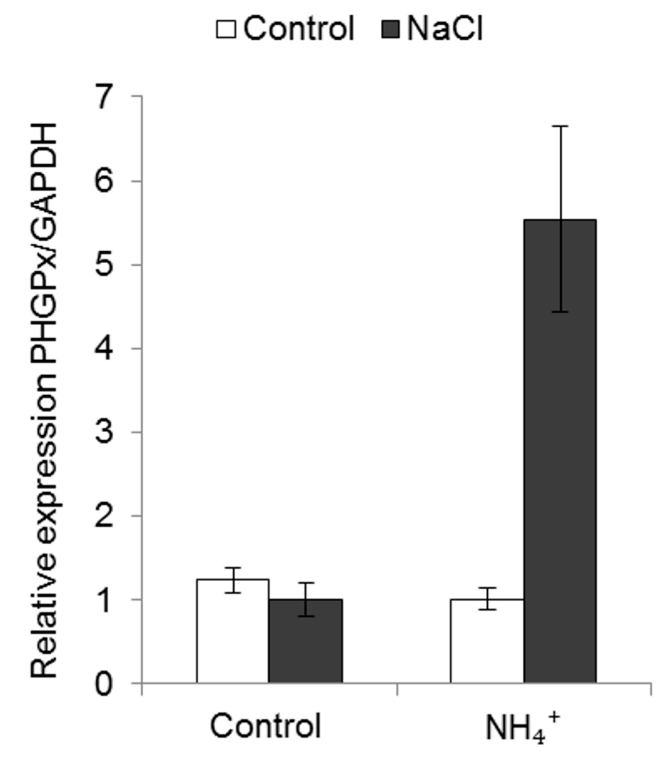

Fig. 7. Effect of $\mathrm{NH}_{4}{ }^{+}$treatment on the PHGPx expression in the citrange Carrizo plants upon salt stress. Total RNA was isolated from leaves at $14 \mathrm{~d}$ after addition of $\mathrm{NaCl}(90 \mathrm{mM})$ converted into cDNA, and was subjected to a RT-qPCR analysis. The results were normalized to the GAPDH gene expression measured in the same samples. The data show the average of three independent experiments obtained with a pool of 10 plants per point \pm SE. The experiment was repeated three times with similar results. 